\title{
Pemberian Layanan Keluarga Berencana Berpengaruh Penting Terhadap Kejadian Unmet Need: Analisis Lanjut Data SDKI 2017
}

\author{
Helmi Safitri $^{{ }^{*}}$, Kemal N. Siregar ${ }^{2}$, Tris Eryando ${ }^{2}$ Rahmadewi $^{3}$, Milla Herdayati ${ }^{2}$, \\ Dian Kristiani Irawaty ${ }^{3}$ \\ ${ }^{\text {I} P r o g r a m ~ S t u d i ~ M a g i s t e r ~ I l m u ~ K e s e h a t a n ~ M a s y a r a k a t, ~ P e m i n a t a n ~ B i o s t a t i s t i k a ~}$ \\ Fakultas Kesehatan Masyarakat Universitas Indonesia \\ ${ }^{2}$ Departemen Kependudukan dan Biostatistika Fakultas Kesehatan Masyarakat Universitas Indonesia \\ ${ }^{3}$ Badan Kependudukan dan Keluarga Berencana Indonesia \\ *Korespondensi: Helmi Safitri-helmi.safitri@ mail.com
}

\begin{abstract}
Abstrak
Penelitian ini dilakukan untuk menilai sejauh mana pengaruh pemberian layanan KB terhadap unmet need pada wanita menikah usia 15-49 tahun. Unmet need merupakan fenomena dalam bidang kependudukan yang memerlukan penanganan serius dan segera karena dapat menghambat peningkatan CPR dan penurunan TFR. Pemberian layanan KB merupakan hal penting dalam memenuhi kebutuhan seseorang untuk memilih dan menggunakan alat KB yang tepat sesuai dengan kebutuhannya (tidak terjadi unmet need). Penelitian ini merupakan analisis lanjut data SDKI 2017, yang merupakan penelitian potong lintang pada wanita menikah usia 15-49 tahun. Jumlah sampel tersedia sebanyak 35.681 wanita. Analisis hubungan antara varaibel dependen dengan independen menggunakan uji chi square, dan pengaruh pemberian layanan KB terhadap unmet need diuji dengan regresi logistik ganda. Hasil penelitian menunjukkan bahwa pemberian layanan KB yang kurang terakses oleh wanita berpeluang 2,27 untuk mengalami kejadian unmet need dibandingkan dengan mereka yang mempunyai akses (95\% CI: 1,95-2,64). Penelitian ini merekomendasikan, peningkatan akses ke pemberian layanan KB bagi wanita untuk memperoleh informasi KB dan layanan alat KB, terutama bagi mereka yang tidak bekerja, tinggal di perkotaan dan memiliki banyak anak.
\end{abstract}

Kata Kunci: unmet need, keluarga berencana, pemberian layanan KB

\section{The Provision of Family Planning Services Has Important Impact on Unmet Need in Indonesia: Analysis of the IDHS 2017 Data}

\begin{abstract}
This study was conducted to assess the extent of the effect of family planning services delivery on unmet needs. Unmet need is a phenomenon in the population sector that requires serious and immediate handling because it can hamper the increase in CPR and decrease the TFR. Family planning services delivery is important in fulfilling a person's need to select and use the right contraceptive device according to their needs (there is no unmet need). This study is a further analysis of the IDHS 2017 data, which is a cross-sectional study of married women aged 15-49 years. The number of samples was 35,68. Analysis of the relationship between the dependent and independent variables using the chi-square test and the effect of family planning services delivery on unmet need was tested by multiple logistic regression. The results showed that women who had less access to family planning services delivery had a 2.27 chance of experiencing unmet need events compared to those who had access (95\% CI: 1.95-2.64). This study recommends increasing access to family planning services for women to obtain family planning information and family planning services, especially for those who do not work, live in urban areas, and have many children.
\end{abstract}

Key Words: unmet need, family planning, FP service delivery 


\section{PENDAHULUAN}

Pada tahun 2017, diseluruh dunia diperkirakan $63,0 \%$ wanita menikah atau hidup bersama pada usia reproduksi menggunakan beberapa bentuk kontrasepsi, termasuk metode kontrasepsi modern atau tradisional. Tetapi $12,0 \%$ wanita menikah atau hidup bersama tersebut diperkirakan memiliki kebutuhan yang tidak terpenuhi (unmet need) untuk keluarga berencana dan diproyeksikan bahwa unmet need akan tetap di atas $10 \%$ di seluruh dunia sampai tahun 2030 (1).

Pada periode tahun 1991-2017, angka pemakaian kontrasepsi (Contraceptive Prevalence Rate/CPR) di Indonesia terus meningkat dari $49,7 \%$ menjadi $65,6 \%$. Namun kondisi tersebut masih diberengi dengan adanya angka unmet need (11\%) yang angkanya masih berada diatas target (9,9\%) (2-4). Unmet need didefinisikan sebagai persentase wanita menikah yang ingin menghentikan atau menunda kelahiran anak tetapi tidak menggunakan metode kontrasepsi apa pun untuk mencegah kehamilan (5).

Unmet need sampai saat ini masih dikatakan bermasalah bila dilihat dari trennya. Tren kejadian unmet need di dunia belum mengalami perubahan yang begitu berarti, dimana pada periode waktu 19902005 sebesar $13,1 \%$ menjadi $12,3 \%$ pada 1995, kemudian menjadi $11,5 \%$ pada tahun
2000 dan 10,9\% pada tahun 2005. Selanjutnya pada tahun 2009 kejadian unmet need menjadi $11,2 \%$ dan pada tahun 2017 menjadi 12\% (1,6). Berdasarkan data dari Population Reference Bureau (2019) diketahui bahwa Indonesia menepati urutan keempat dengan angka unmet need tertinggi (11\%) di Asia Tenggara setelah Timur Leste $(25,3 \%)$, Philipina $(16,7 \%)$ dan Myanmar (16,2\%) (7).

Sama halnya dengan tren unmet need yang terjadi di Indonesia. Terlihat dari tahun ke tahun unmet need belum menunjukkan perubahan yang begitu berarti. Kejadian unmet need yang awalnya sebesar $17 \%$ pada tahun 1991 menjadi 15\% pada tahun 1994 dan mejadi 14\% pada tahun 1997, kemudian menjadi $13 \%$ pada tahun 2003. Pada tahun 2007 angka unmet need masih tetap berada di angka 13\%. Selanjutnya, diantara hasil SDKI 2007 sampai 2012, total unmet need di Indonesia hanya mengalami perubahan dari $13 \%$ menjadi $11 \%$. Pada tahun berikutnya, yaitu tahun 2017 angka unmet need kembali menetap diangka yang sama $(11 \%)$ dan menunjukkan bahwa tren angka unmet need masih terkesan terus mendatar hingga saat ini $(5,8)$.

Unmet need harus terus menjadi perhatian khusus bagi pemerintah, karena terlihat bahwa persentase unmet need masih belum menunjukkan perubahan yang signifikan dari tahun ke tahun dan terbilang 
sering menentap diangka yang sama, kemudian hingga saat ini angka unmet need juga masih terus berada diatas dari target yang ditetapkan.

Angka unmet need yang tinggi juga menunjukkan bahwa ada kemungkinan pelayanan KB pada sebagian masyarakat tidak terpenuhi. Meskipun saat ini pemerintah telah berupaya untuk meningkatkan kesertaan $\mathrm{KB}$ di seluruh wilayah Indonesia dengan berbagai program yang ada, namun kebutuhan KB yang tidak terpenuhi masih tinggi. Pemerintah sebagai penyedia layanan bertanggung jawab dan berupaya menyediakan alat kontrasepsi yang dibutuhkan masyarakat sebagai klien (9).

Persoalan muncul ketika alat kontrasepsi yang didistribusikan tidak sesuai dengan keinginan masyarakat. Jeda waktu pengusulan dengan realisasi alat kontrasepsi yang cukup panjang menjadi salah satu faktor penyebab perubahan pemilihan alat kontrasepsi. Pertimbangan administrasi penyediaan alat kontrasepsi menjadi persoalan lain pada kasus unmet need. Salah satu indikator keberhasilan program KB, baik dalam tatanan Indonesia maupun global, adalah terpenuhinya kebutuhan alat kontrasepsi (9).

Unmet need merupakan suatu masalah yang bersifat multidimensional karena dipengaruhi oleh beragam faktor. Menurut Bertrand (1980), yang mempengaruhi pemakaian kontrasepsi ada tiga faktor antara lain adalah faktor sosiodemografi (pendidikan, pendapatan, status pekerjaan, wilayah tempat tinggal, usia, jumlah anak hidup, suku/ras dan agama), faktor sosiopsikologi (sikap terhadap KB, pengetahuan tentang alat/cara $\mathrm{KB}$ ) dan faktor pemberi layanan (kunjungan petugas, ketersediaan $\mathrm{KB}$, sumber informasi $\mathrm{KB}$ ) (10).

Penelitian yang dilakukan Korra (2002) juga menyatakan bahwa unmet need dipengaruhi oleh banyak faktor yaitu faktor demografi (usia, usia pertama menikah, jumlah anak hidup, jumlah anak ideal, jumlah pernikahan), faktor sosioekonomi (status migrasi, pendidikan, agama, suku/ras, status bekerja, paparan media, dikunjungi petugas $\mathrm{KB}$, mengunjungi fasilitas kesehatan, tempat tinggal) dan determinan terdekat (pengetahuan tentang $\mathrm{KB}$, persetujuan suami, diskusi dengan pasangan tentang KB (11).

Berdasarkan penelitian Khalil (2018) menyatakan bahwa alasan utama terjadinya unmet need adalah kurangnya pengetahuan tentang metode keluarga brencana, tidak dapat diaksesnya metode keluarga berencana, pengalaman efek samping karena pengguanaan kontrasepsi dan larangan agama. Selain itu, kebutuhan yang tidak terpenuhi secara signifikan tinggi di antara wanita dengan kelompok usia yang lebih rendah dan lebih tua. Tingkat 
pendidikan yang rendah secara signifikan terkait dengan unmet need (12).

Kualitas pelayanan di tingkat masyarakat memiliki efek kuat pada penggunaan kontrasepsi. Hal ini menunjukkan bahwa keuntungan yang besar dalam penggunaan kontrasepsi dapat diwujudkan dengan meningkatkan kualitas pelayanan (13). Peran pemberi pelayanan $\mathrm{KB}$ sangat penting untuk menciptakan pelayanan KB yang berkualitas dan untuk menghindari terjadinya kejadian unmet need. Hasil penelitian yang dilakukan oleh Safitri (2019) menunjukkan bahwa kurangnya peran petugas pelayanan $\mathrm{KB}$ dalam memberikan informasi tentang penggunaan alat kontrasepsi memiliki peluang 18 kali lebih besar untuk terjadinya unmet need (14).

Pemberian layanan KB merupakan hal yang sangat penting bagi klien sebagai pihak pertama yang merasakan manfaat dari layanan tersebut. Pelaksanaan pelayanan $\mathrm{KB}$ baik oleh pemerintah maupun swasta harus sesuai standar pelayanan yang ditetapkan untuk menjamin pelayanan yang berkualitas dengan memenuhi: pilihan metode kontrasepsi (cafetaria system); informasi kepada klien; kompetensi teknis petugas; hubungan interpersonal antara petugas dan klien; mekanisme yang menjamin kelanjutan pemakai KB; pelayanan yang memadai (15).
Kualitas layanan terhadap pemilihan alat kontrasepsi dapat meningkatkan cakupan pengguna keluarga berencana. Bentuk pelayanan KB yang diberikan oleh pemberi layanan bukan sekedar menyediakan alat kontrasepsi, tetapi memperhatikan kebutuhan sosial dan kesehatan calon akseptor. Pemberi pelayanan KB dituntut memberikan informasi terkait dengan pilihan metode, termasuk manfaat dan risiko yang ditimbulkannya, tempat konseling, tempat pelayanan penggunaan alat kontrasepsi, dan keberlanjutan pelayanan (9). Penelitian ini bertujuan untuk menilai sejauhmana pengaruh pemberian layanan KB terhadap kejadian unmet need pada wanita menikah usia 15-49 tahun di Indonesia.

\section{METODE}

Data yang digunakan diambil dari dataset Wanita Usia Subur (WUS) dari Survei Demografi Kesehatan Indonesia (SDKI) 2017 yang menggunakan desain studi cross sectional, yang diperoleh dari website DHS (Demographic and Health Survey) yang sudah mendapatkan izin. Populasi penelitian yaitu seluruh wanita usia 15-49 tahun di 34 provinsi di Indonesia, sedangkan sampel penelitian ini hanya wanita menikah dengan usia 15-49 tahun (35.681 orang). Persiapan data dilakukan dengan tahapan mempelajari 
variabel-variabel penelitian dari daftar pertanyaan SDKI 2017, membuat kontruksi variabel komposit dari beberapa pertanyaan, melakukan pengkodean ulang (recode) terhadap variabel sesuai dengan kebutuhan penelitian kemudian membersihkan data (cleaning) yang tidak ikut dianalisis, baik data yang tidak sesuai maupun yang tidak lengkap. Penelitian ini merupakan analisis lanjutan dari data SDKI sehingga perlu dilakukan pembobotan untuk menyamakan probabilitas responden terpilih.

Unmet need KB didefinisikan sebagai persentase wanita usia subur dan aktif secara seksual (menikah/tinggal bersama) tetapi tidak menggunakan metode kontrasepsi apapun namun tidak menginginkan anak lagi atau ingin menunda kelahiran dalam dua tahun kedepan. Termasuk diantaranya yaitu semua wanita hamil yang kehamilannya tidak diinginkan (unwanted) atau tidak sesuai dengan waktu yang diinginkan (mistimed), semua wanita amenore pasca persalinan yang tidak menggunakan $\mathrm{KB}$ dimana kelahiran terakhirnya tidak diinginkan atau tidak tepat waktu, semua wanita subur yang tidak hamil atau amenore pasca persalinan dan tidak menginginkan anak lagi (ingin membatasi jumlah anak) atau yang ingin menunda kelahiran anak setidaknya selama dua tahun atau tidak tahu kapan atau tidak yakin apakah ingin hamil lagi (16).

Berdasarkan dari kerangka teori yang dikemukakan oleh Bertrand (1980) maka yang menjadi variabel dependen adalah status unmet need. Pemberian layanan KB sebagai variabel independen yang dibangun dari komponen varaibel yang kemudian dikelompokkan menjadi dua kategori yaitu pemberian layanan KB kurang terakses yaitu jika responden tidak mendapatkan akses informasi KB melalui media massa/kunjungan/ kontak personal dengan petugas serta tidak menggunakan $\mathrm{KB}$ dan pemberian layanan $\mathrm{KB}$ terakses yaitu jika responden mendapatkan akses informasi KB melalui media massa/kunjungan/kontak personal dengan petugas serta setidaknya pernah menggunakan salah satu alat/cara $\mathrm{KB}$ ), sedangkan variabel perancunya adalah pendidikan, status pekerjaan, status ekonomi, wilayah tempat tinggal, jumlah anak yang masih hidup, persetujuan suami tentang $\mathrm{KB}$, diskusi suami dan istri.

Analisis univariabel digunakan untuk menganalisis distribusi frekuensi dari semua variabel penelitian dan analisis bivariabel dilakukan untuk melihat hubungan antara variabel dependen dengan variabel independen serta variabel-variabel perancu dengan menggunakan uji chisquare. Jika variabel perancu memiliki nilai $\mathrm{p}<0,25$ dari hasil uji chi-square maka variabel tersebut dapat masuk ke dalam 
analisis multivriabel. Kemudian pada analisis multivariabel digunakan uji regresi logistik ganda dengan model faktor risiko untuk mengukur pengaruh pemberian layanan $\mathrm{KB}$ terhadap kejadian unmet need setelah mengontrol beberapa variabel perancu yang signifikan. Hanya model akhir akan dibahas dalam penelitian ini. Izin etis dari penelitian ini diperoleh dari Fakultas Kesehatan Masyarakat, Universitas Indonesia pada 10 Juli 2020.

\section{HASIL}

Hasil menunjukkan bahwa sebanyak 10,6\% (selanjutnya dilaporkan menjadi $11 \%$ sesuai laporan SDKI) (95\% CI=10,2-
$11,1 \%)$ wanita mengalami unmet need. Kemudian masih tedapat sebesar $8,5 \%$ wanita yang kurang dapat mengakses pemberian layanan KB. Responden cenderung lebih banyak yang berpendidikan rendah $(61,6 \%)$, bekerja $(55,7 \%)$, berstatus ekonomi rendah (58,3\%), dan memiliki $\leq 2$ anak yang masih hidup $(70,1 \%)$. Proporsi reponden yang tinggal di daerah perkotaan hampir sama dengan mereka yang tinggal di daerah pedesaan $(48,4 \%$ di perkotaan dan $51,6 \%$ di pedesaan). Persentase dari masing-masing karakteristik responden dapat dilihat pada Tabel 1.

Tabel 1. Hasil Temuan Literatur

\begin{tabular}{|c|c|c|c|}
\hline Variabel & $\mathbf{n}$ & $\%$ & $95 \% \mathrm{CI}$ \\
\hline \multicolumn{4}{|l|}{ Status Unmet Need } \\
\hline Unmet need & 3.784 & 10,6 & $10,2-11,1$ \\
\hline Bukan unmet need & 31.897 & 89,4 & $88,9-89,8$ \\
\hline \multicolumn{4}{|l|}{ Pemberian layanan $\mathrm{KB}$} \\
\hline Kurang terakses & 3031 & 8,5 & $8,1-8,9$ \\
\hline Terakses & 32.650 & 91,5 & $91,1-91,9$ \\
\hline \multicolumn{4}{|l|}{ Pendidikan } \\
\hline Pendidikan Rendah & 21.996 & 61,6 & $60,5-62,8$ \\
\hline Pendidikan Tinggi & 13.685 & 38,4 & $37,2-39,5$ \\
\hline \multicolumn{4}{|l|}{ Status Pekerjaan } \\
\hline Tidak Bekerja & 15.791 & 44,3 & $43,4-45,1$ \\
\hline Bekerja & 19.890 & 55,7 & $54,9-56,6$ \\
\hline \multicolumn{4}{|l|}{ Status Ekonomi } \\
\hline Ekonomi Rendah & 20.784 & 58,3 & $56,9-59,6$ \\
\hline Ekonomi Tinggi & 14.897 & 41,7 & $40,4-43,1$ \\
\hline \multicolumn{4}{|l|}{ Wilayah Tempat Tinggal } \\
\hline Pedesaan & 18.413 & 51,6 & $50,8-52,4$ \\
\hline Perkotaan & 17.268 & 48,4 & $47,6-49,2$ \\
\hline \multicolumn{4}{|l|}{ Jumlah Anak Hidup } \\
\hline$>2$ & 10.652 & 29,9 & $29,1-30,6$ \\
\hline$\leq 2$ & 25.028 & 70,1 & $69,4-70,9$ \\
\hline \multicolumn{4}{|l|}{ Persetujuan Suami tentang KB } \\
\hline Tidak Setuju & 35.309 & 99,0 & $98,8-99,1$ \\
\hline Setuju & 372 & 1,0 & $0,9-1,2$ \\
\hline \multicolumn{4}{|l|}{ Diskusi Dengan Suami } \\
\hline Tidak & 21.775 & 61,0 & $59,9-62,1$ \\
\hline $\mathrm{Ya}$ & 13.906 & 39,0 & $37,9-40,1$ \\
\hline
\end{tabular}


Tabel 2. Hubungan Kejadian Unmet Need Berdasarkan Variabel Independen (Pemberian Layanan KB) dan Variabel Perancu Pada Wanita Menikah Usia 15-49 Tahun di Indonesia 2017 (n=35.681)

\begin{tabular}{|c|c|c|c|c|}
\hline \multirow{2}{*}{ Variabel } & \multicolumn{2}{|c|}{ Status Unmet Need (\%) } & \multirow{2}{*}{$\mathbf{P}$} & \multirow{2}{*}{$\begin{array}{c}\text { OR } \\
(95 \% \mathrm{CI})\end{array}$} \\
\hline & Unmet Need & Bukan Unmet Need & & \\
\hline Pemberian layanan KB & & & \multirow{3}{*}{$<0,0001$} & \multirow{3}{*}{$\begin{array}{c}2,8 \\
(2,5-3,2)\end{array}$} \\
\hline Kurang terakses & 22,9 & 77,1 & & \\
\hline Terakses & 9,5 & 90,5 & & \\
\hline Pendidikan & & & \multirow{3}{*}{0,560} & \multirow{3}{*}{$\begin{array}{c}1,0 \\
(0,9-1,1)\end{array}$} \\
\hline Pendidikan Rendah & 10,8 & 89,2 & & \\
\hline Pendidikan Tinggi & 10,5 & 89,5 & & \\
\hline Status Pekerjaan & & & \multirow{3}{*}{0,180} & \multirow{3}{*}{$\begin{array}{c}1,1 \\
(1,0-1,2)\end{array}$} \\
\hline Tidak Bekerja & 10,9 & 89,1 & & \\
\hline Bekerja & 10,4 & 89,6 & & \\
\hline Status Ekonomi & & & \multirow{3}{*}{0,183} & \multirow{3}{*}{$\begin{array}{c}0,9 \\
(0,9-1,0)\end{array}$} \\
\hline Ekonomi Rendah (kuntil 1,2,3) & 10,4 & 89,6 & & \\
\hline Ekonomi Tinggi (kuintil 4,5) & 10,9 & 89,1 & & \\
\hline Wilayah Tempat Tinggal & & & \multirow{3}{*}{0,001} & \multirow{3}{*}{$\begin{array}{c}0,9 \\
(0,8-0,9)\end{array}$} \\
\hline Pedesaan & 9,9 & 90,1 & & \\
\hline Perkotaan & 11,3 & 88,7 & & \\
\hline Jumlah Anak Hidup & & & \multirow{3}{*}{$<0,0001$} & \multirow{3}{*}{$\begin{array}{c}1,6 \\
(1,4-1,7)\end{array}$} \\
\hline$>2$ & 13,7 & 86,3 & & \\
\hline$\leq 2$ & 9,3 & 90,7 & & \\
\hline Persetujuan Suami & & & \multirow{3}{*}{0,888} & \multirow{3}{*}{$\begin{array}{c}1,03 \\
(0,7-1,6)\end{array}$} \\
\hline Tidak Setuju & 10,6 & 89,4 & & \\
\hline Setuju & 10,3 & 89,75 & & \\
\hline Diskusi dengan Suami & & & \multirow{3}{*}{$<0,0001$} & \multirow{3}{*}{$\begin{array}{c}1,2 \\
(1,1-1,3)\end{array}$} \\
\hline Tidak Diskusi & 11,2 & 88,8 & & \\
\hline Diskusi & 9,6 & 90,4 & & \\
\hline
\end{tabular}

Tabel 3. Model Akhir Analisis Regresi Logistik Ganda Mengenai Pengaruh Pemberian Layanan KB Terhadap Kejadian Unmet Need Pada Wanita Menikah Usia 15-49 Tahun Di Indonesia 2017 (n=35.681)

\begin{tabular}{lcccc}
\hline Variabel & $\boldsymbol{\beta}$ & $\mathbf{P}$ & Adjusted OR & 95\% CI \\
\hline $\begin{array}{l}\text { Pemberian Layanan KB } \\
\quad \text { Kurang terakses }\end{array}$ & 0,819 & $<0,0001$ & 2,27 & $1,95-2,64$ \\
$\quad$ Terakses & & & 1,0 & \\
$\begin{array}{l}\text { Status Pekerjaan } \\
\quad \text { Tidak Bekerja } \\
\quad \text { Bekerja }\end{array}$ & 0,094 & 0,032 & 1,10 & $1,01-1,20$ \\
$\begin{array}{l}\text { Wilayah Tempat Tinggal } \\
\quad \text { Pedesaan }\end{array}$ & & & 1,0 & \\
$\quad \begin{array}{l}\text { Perkotaan } \\
\text { Jumlah Anak Hidup }\end{array}$ & $-0,210$ & $<0,0001$ & 0,81 & $0,74-0,89$ \\
$\quad>2$ & & & 1,0 & \\
$\quad \leq 2$ & 0,355 & $<0,0001$ & 1,43 & $1,29-1,57$ \\
\hline
\end{tabular}

Pemberian layanan KB yang kurang terakses menyebabkan tingginya angka unmet need yaitu sebesar 22,9\% dibandingkan yang dapat diakses yaitu hanya sebesar 9,5\%. Selain pemberian layanan $\mathrm{KB}$, ada beberapa faktor lain yang berhubungan dengan unmet need yaitu status pekerjaan, wilayah tempat tinggal, jumlah anak hidup dan diskusi tentang KB. Selanjutnya hasil uji bivariabel ini juga digunakan untuk menentukan variabel yang akan masuk dalam uji multivariabel (nilai 
$\mathrm{p}<0,25)$, yaitu variabel pemberian layanan $\mathrm{KB}$, status pekerjaan, status ekonomi, wilayah tempat tinggal, jumlah anak hidup, dan diskusi dengan suami. Temuan ini dapat dilihat lebih jelas pada Tabel 2.

Hasil dari model akhir analisis regresi logistik ganda menunjukkan bahwa pemberian layanan $\mathrm{KB}$ berpengaruh terhadap unmet need setelah dikontrol oleh variabel perancu (status pekerjaan, wilayah tempat tinggal dan jumlah anak hidup) dengan adjusted OR adalah 2,27 (95\% $\mathrm{CI}=1,95-2,64)$. Temuan ini dapat dilihat lebih jelas pada Tabel 3.

\section{PEMBAHASAN}

Hasil dari penelitian menunjukkan bahwa tingkat unmet need di Indonesia masih berada diatas angka target nasional. Dimana dari 35.681 wanita menikah usia 15-49 tahun, terdapat $11 \%$ (95\% CI: 10,2\%$11,1 \%)$. Hasil tersebut masih sama dengan hasil dari laporan SDKI 2012 sebelumnya yaitu $11,4 \%$ (8). Hal ini menunjukkan bahwa kejadian unmet need masih banyak terjadi pada wanita menikah usia 15-49 tahun dan belum menunjukkan perubahan yang signifikan dari tahun ke tahun.

Unmet need merupakan fenomena dalam bidang kependudukan yang penting untuk diperhatikan. Penurunan unmet need akan sama besarnya dengan peningkatan jumlah akseptor dan penurunan angka kelahiran total. Estimasi dari ukuran dan komposisi populasi wanita yang mengalami kejadian unmet need dapat berguna dalam merencanakan program keluarga berencana dan kesehatan reproduksi.

Berdasarkan hasil penelitian, ternyata pemberian layanan $\mathrm{KB}$ sebagai varaibel independen utama memiliki hubungan yang signifikan dengan kejadian unmet need. Pemberian layanan KB memiliki hubungan yang sangat penting dengan kejadian unmet need. Dimana wanita yang kurang dapat mengakses (responden yang tidak pernah mendapatkan informasi tentang $\mathrm{KB}$ dari berbagai sumber informasi (media massa/kunjungan petugas/kontak personal) serta tidak pernah menggunakan alat/cara) pemberian layanan $\mathrm{KB}$ akan memiliki kejadian unmet need yang tinggi yaitu sebesar $22,9 \%$.

Sedangkan kejadian unme need pada pemberian layanan $\mathrm{KB}$ yang terakses (responden yang pernah mendapatkan informasi tentang $\mathrm{KB}$ dari salah satu sumber informasi serta penah menggunakan salah satu cara/alat $\mathrm{KB}$ ) hanya sebesar 9,5\%, Hal ini menunjukkan kurang teraksesnya pemberian layanan $\mathrm{KB}$ tentunya akan menjadi penghalang para klien untuk mendapatkan akses informasi dan layanan alat/cara KB sehingga menghambat mereka dalam memenuhi kebutuhan akan kontrasepsi dan akhirnya 
menjadikan angka unmet need di Indonesia terus tinggi.

Menurut Oliver \& Mossialos (2004) akses terhadap pelayanan kesehatan merupakan kesesuaian antara kebutuhan masyarakat dengan yang disediakan oleh sistem pelayanan kesehatan dalam konteks ketersediaan dan penggunaannya secara aktual. Ketersediaan menjelaskan mengenai pemberian layanan yang tersedia dan dapat diberikan kepada masyarakat, sedangkan penggunaan secara aktual menjelaskan mengenai kenyataan pemberian layanan yang diterima oleh masyarakat yang membutuhkan (17). Meningkatkan akses pemberian layanan adalah langkah penting menuju peningkatan penggunaan metode didaerah dengan unmet need yang tinggi (18).

Selain pemberian layanan KB, diketahui wilayah tempat tinggal, jumah anak hidup, diskusi tentang $\mathrm{KB}$ dengan suami juga merupakan faktor yang berhubungan dengan unmet need. Proporsi unmet need pada responden yang tinggal di perkotaan yaitu sebesar $11,3 \%$, sedangkan proporsi unmet need pada responden yang tinggal di pedesaan sebesar 9,9\%. Kemudian jumlah anak hidup yang dimiliki juga berhubungan dengan kejadian unmet need. Wanita yang memiliki anak hidup lebih dari 2 orang memiliki rasio odds 1,56 lebih besar untuk mengalami unmet need dibandingkan jumlah anak yang dimiliki kurang dari sama dengan 2 orang. Sejalan dengan penelitian yang dilakukan oleh Wulifan et al (2017) yang menunjukkan bahwa terdapat hubungan positif antara jumlah anak hidup dan kejadian unmet need, dimana jumlah anak yang semakin banyak atau lebih dari 4, memiliki kecenderungan lebih besar untuk mengalami unmet need. (19).

Meskipun sebenarnya penelitian ini mendalilkan sebaliknya, bahwa wanita yang memiliki banyak anak benar-benar ingin mencegah kehamilan selanjutnya, tetapi nyatanya mereka tidak berdaya untuk melakukannya. Hal tersebut kemungkinan karena terhambat dalam mengontrol kesuburan mereka karena tidak dapat mendikusikan masalah ini dengan pasangan mereka atau pasangan mereka tidak menyetujui penggunaan alat/cara KB. Selanjutnya, diskusi dengan suami juga menunjukkan hubungan yang signifikan dengan kejadian unmet need. Dimana wanita yang tidak melakukan diskusi dengan suami mengalami unmet need sebesar $11,2 \%$, sedangkan yang melakukan diskusi mengalami unmet need yaitu sebesar $9,6 \%$.

Untuk melihat sebarapa besar pengaruh pemberian layanan $\mathrm{KB}$ di Indonesia dan mengingat ada banyak variabel lain yang turut berhubungan maka analisis lanjut multivariabel dengan regresi logistik ganda menunjukkan bahwa 
pemberian layanan KB (mulai dari pemberian informasi tentang $\mathrm{KB}$ sampai dengan penggunaan alat/cara $\mathrm{KB}$ ) berpengaruh terhadap kejadian unmet need, setelah dikontrol oleh status pekerjaan, wilayah tempat tinggal dan jumlah anak hidup $(\mathrm{p}<0,0001)$. Dimana pemberian layanan $\mathrm{KB}$ yang kurang terakses oleh wanita menikah usia 15-49 tahun memiliki peluang 2,27 (95\% CI: 1,95-2,64) lebih besar untuk mengalami unmet need setelah dikontrol oleh variabel perancu (9).

Hal tersebut menunjukkan bahwa pemberian layanan $\mathrm{KB}$ berpengaruh penting terhadap kejadian unmet need. Peningkatan angka unmet need disebabkan oleh melemahnya akses penduduk terhadap pelayanan KB (9). Mereka yang memiliki akses penuh ke layanan kesehatan secara signifikan lebih kecil kemungkinannya untuk mengalami unmet need (20). Penelitian yang dilakukan oleh Kartika (2014), menyatakan bahwa akses informasi menunjukkan memiliki pengaruh terhadap kejadian unmet need (21).

Sejalan dengan Susesno (2011), menyatakan bahwa pilihan metode, kompetensi teknis tenaga kesehatan, informasi yang diberikan kepada klien melalui hubungan interpersonal, mekanisme tindak lanjut dan kontinuitas merupakan hal penting yang harus diperhatikan dalam pemberian layanan $\mathrm{KB}$ guna meningkat pengetahuan akseptor tentang $\mathrm{KB}$ dan penerimaan metode yang efektif bagi wanita, serta mempengaruhi pilihan metode (22).

Semakin baik dan teraksesnya pemberian layanan KB yang dilakukan, maka semakin besar kemungkinan para wanita menggunakan alat/cara KB sehingga dapat menurunkan angka unmet need. Hal tersebut menunjukkan perlunya perluasan upaya KB untuk mengisi kesenjangan pengetahuan dan komunikasi serta perluasan informasi (18). Akses dan kualitas pemberian layanan KB yang baik yang disediakan memiliki pengaruh penting untuk kelangsungan penggunaan alat/cara $\mathrm{KB}$ bagi akseptor dan calon akseptor sehingga dapat mengatasi masalah unmet need.

Menurut Bruce (1990), pemberian informasi adalah suatu elemen penting di dalam kualitas pemberian layanan KB dan tentunya berkontribusi terhadap penerimaan alat/cara $\mathrm{KB}$ dan kepuasan klien. Maka dari itu, pemberian informasi dan konseling menjadi kesempatan terbaik yang dapat digunakan untuk membantu klien dalam mengambil keputusan untuk memilih alat/cara KB yang akan digunakan. Pemberian informasi maupun konseling yang tepat sangat membantu dalam meningkatkan kepesertaan KB baru dan mengurangi angka drop out (15).

Informasi adalah kekuatan, karena itu adalah dasar pengambilan keputusan yang 
tepat baik bagi individu maupun pemerintah. Menjadikan informasi tentang $\mathrm{KB}$, terkait berbagai macam pilihan alat/cara KB, alasan harus menggunakan alat/cara $\mathrm{KB}$, beserta kerugian dan keuntungannya baik dari aspek kesehatan, sosial sampai dengan ekonomi, tersebar seluas-luasnya sehingga mudah dijangkau, tetapi lengkap dan akurat (23).

Oleh karena itu ketersediaan informasi dan layanan alat/cara KB telah ditetapkan menjadi hal yang sangat penting dalam mengatasi kejadian unmet need (23). Ketersediaan informasi yang mendalam dan benar memungkinkan wanita untuk memahami semua aspek yang berkaitan dengan manfaat, risiko, dan cara meminimalkan risiko yang dihasilkan dari penggunaan KB (24).

Ketersediaan layanan dan staf profesional yang dapat mengurangi kekhawatiran wanita saat melakukan pemasangan dan penggantian alat $\mathrm{KB}$. Ketersediaan dan kemudahan memperoleh dan keterjangkauan dari berbagai jenis alat $\mathrm{KB}$ membuat wanita memiliki pilihan alat KB yang mereka butuhkan sesuai dengan kondisi masing-masing (24). Pemberian layanan KB yang berkualitas dan terakses dengan baik tentunya berdampak pada kepuasan yang dilayani dan terpenuhinya tata cara penyelenggraan pemberian layanan KB sesuai dengan kode etik dan standar pelayanan yang telah ditetapkan (25).

\section{KESIMPULAN}

Angka unmet need di Indonesia yang masih berada diatas angka target sangat dipengaruhi oleh pemberian layanan KB. Pemberian layanan KB yang kurang terakses memiliki kejadian unmet need $22,9 \%$, artinya responden yang tidak pernah mendapatkan informasi tentang $\mathrm{KB}$ dari berbagai sumber informasi (media massa/kunjungan petugas/kontak personal) serta tidak pernah menggunakan alat/cara akan menyebabkan tingginya angka unmet need dibandingkan dengan pemberian layanan KB yang dapat terakses (responden yang pernah mendapatkan informasi tentang KB dari salah satu sumber informasi serta penah menggunakan salah satu cara/alat KB) yaitu sebesar 9,5\%. Pemberian layanan $\mathrm{KB}$ memiliki pengaruh yang signifikan terhadap unmet need pada wanita menikah usia 15-49 tahun di Indonesia, setelah dikontrol oleh variabel status pekerjaan, wilayah tempat tinggal dan jumlah anak hidup, dengan OR sebesar $2,27(95 \% \mathrm{CI}=1,95-2,64)$.

Oleh karana itu, penelitian ini merekomendasikan, peningkatan akses ke pemberian layanan $\mathrm{KB}$ bagi wanita untuk memperoleh informasi KB dan layanan alat $\mathrm{KB}$, terutama bagi mereka yang tidak bekerja, tinggal di perkotaan dan memiliki 
anak banyak, sehingga dapat meningkatkan pengetahuan dan kesadaran untuk menggunakan salah satu alat/cara KB yang sesuai dengan kebutuhan mereka.

\section{DAFTAR PUSTAKA}

1. United Nations. World Family Planning. Dep Econ Soc Aff ST/ESA/SERA/414. 2017;1-43.

2. Badan Perencanaan Pembangunan Nasional. Rencana Pembangunan Jangka Menengah Nasional 20152019. 2014.

3. BKKBN. Strategi Pelaksanaan Program Keluarga Berencana Berbasis Hak untuk Percepatan Akses terhadap Pelayanan Keluarga Berencana dan Kesehatan Reproduksi yang Terintegrasi dalam Mencapai Tujuan Pembangunan Indonesia. 2015;100.

4. BKKBN. Renstra Bkkbn Tahun 20152019. 2016;

5. Badan Pusat Statistik, Badan Koordinasi Keluarga Berencanan Nasional, Kementerian Kesehatan, USAID. Survei Demografi Dan Kesehatan. SDKI. 2018. 1-606 p.

6. Unated Nations, Affairs DD of E and S, Division P. World Contraceptive Use 2010 POP/DB/CP/Rev2010 Regional Averages for Unmet Need for Family Planning. Population Division Department of Economic and Social
Affairs.; 2011.

7. Population Reference Bureau. International Data. 2019.

8. Badan Pusat Statistik, Badan Koordinasi Keluarga Berencanan Nasional, Departemen Kesehatan, Macro International. Survei Demografi dan Kesehatan Indonesia 2012. SDKI. 2013. 16 p.

9. Listyaningsih U, Sumini S, Satiti S. Unmet Need: Konsep Yang Masih Perlu Diperdebatkan. Populasi. 2016;24(1):72-90.

10. Bertrand JT. Audience Research for Improving Family Planning Communication Program. Amerika Serikat: Communication Laboratory Community and Family Study Center Uniersity of Chicago; 1980.

11. Korra A. Attitudes Toward Family Planning and Reasons for Nonuse among Women with Unmet Need for Family Planning in Ethiopia. Care Ethiop. 2002;

12. Khalil SN, Alzahrani MM, Siddiqui AF. Unmet need and demand for family planning among married women of Abha, Aseer Region in Saudi Arabia. Middle East Fertil Soc J. 2018;23(1):31-6.

13. Tappis H, Kazi A, Hameed W, Dahar Z, Ali A, Agha S. The Role of Quality Health Services and Discussion about Birth Spacing in Postpartum 
Contraceptive Use in Sindh, Pakistan:

A Multilevel Analysis. PLoS One. 2015 Oct;10(10).

14. Safitri F, Kana I. Determinan Kejadian Unmet Need KB Di Wilayah Kerja Puskesmas Peukan Bada Kabupaten Aceh Besar Tahun 2019 Determinants of Unmet Need at Working Area of Puskesmas Peukan Bada Aceh Besar in 2019. 2019;5(2).

15. Bruce J. Fundamental Elements of the Quality of Care: A Simple Framework. Stud Fam Plann. 1990;21(2):61.

16. Bradley SEK, Trevor NC, Fishel JD, Westoff CF. Revising Unmet Need for Family Planning: DHS Analytical Studies No. 25. Vol. 4, ICF International Calverton, Maryland, USA. 2012. 483-488 p.

17. Oliver A, Mossialos E. Equity of access to health care: Outlining the foundations for action. J Epidemiol Community Health. 2004;58(8):655-8.

18. Shiferaw S, Spigt M, Seme A, Amogne A, Skrøvseth S, Desta S, et al. Does proximity of women to facilities with better choice of contraceptives affect their contraceptive utilization in rural Ethiopia? PLoS One. 2017 Nov;12(11).

19. Wulifan JK, Jahn A, Hien H, Ilboudo PC, Meda N, Robyn PJ, et al. Determinants of unmet need for family planning in rural Burkina Faso: A multilevel logistic regression analysis. BMC Pregnancy Childbirth. 2017;17(1):1-12.

20. Juarez F, Gayet C, Mejia-Pailles G. Factors associated with unmet need for contraception in Mexico: evidence from the National Survey of Demographic Dynamics 2014. BMC Public Health. 2018;18(1):546.

21. Kartika WDD. Faktor yang Memengaruhi Unmet Need Keluarga Berencana. J Biometrika dan Kependud. 2014;4(1):70-5.

22. Suseno MR. Faktor-faktor yang berpengaruh terhadap kebutuhan Keluarga Berencana yang Tidak Terpenuhi (Unmet Need for Family Planning) di Kota Kediri. J Kebidanan Panti Wilasa. 2011;2(1).

23. Chukwuji CN, Gadanga AT, Sule S, Zainab Y, Zakarriya J. Awareness, access and utilization of family planning information in Zamfara State, Nigeria. Libr Philos Pract. 2018;2018.

24. Thohirun, Kuntoro, Sunarjo, Wibowo A. Social Factors and Unmet Need for Family Planning In District of Jember Indonesia. IOSR J Nurs Heal Sci Ver III. 2015;4(3):19-25.

25. Direktorat Jenderal Bina Gizi dan Kesehatan Ibu dan Anak. Rencana Aksi Nasional Pelayanan Keluarga Berencana 2014-2015. Vol. 77. 2013. 77-80 p. 